\begin{tabular}{|l|l|l||}
\hline \multicolumn{2}{|c|}{ PublisherInfo } \\
\hline \hline PublisherName & $:$ & BioMed Central \\
\hline \hline PublisherLocation & $:$ & London \\
\hline \hline PublisherImprintName & $:$ & BioMed Central \\
\hline \hline
\end{tabular}

\title{
Bisphosphonates inhibit breast and prostate cancer cell invasion
}

\begin{tabular}{|l|l|l||}
\hline \multicolumn{2}{|c|}{ ArticleInfo } \\
\hline \hline ArticleID & $:$ & 3732 \\
\hline \hline ArticleDOI & $:$ & $10.1186 /$ bcr-2000-66695 \\
\hline \hline ArticleCitationID & $:$ & 66695 \\
\hline \hline ArticleSequenceNumber & $:$ & 98 \\
\hline \hline ArticleCategory & $:$ & Paper Report \\
\hline ArticleFirstPage & $:$ & 1 \\
\hline \hline ArticleLastPage & $:$ & 4 \\
\hline \hline & & RegistrationDate : 2000-8-22 \\
\hline ArticleHistory & $:$ & OnlineDate \\
\hline \hline ArticleCopyright & $:$ & Current Science Ltd2000-8-22 \\
\hline \hline ArticleGrants & $:$ & \\
\hline \hline ArticleContext & $:$ & 1305822 \\
\hline \hline
\end{tabular}


Richard de Boer, ${ }^{\text {Aff1 }}$

Aff1 Austin and Repatriation Medical Centre, Victoria, Australia

\section{Keywords}

Bisphosphonates, invasion, bone metastases

\section{Introduction}

Breast cancer cells commonly invade bone, induce osteoclast activity and subsequent osteolysis leading to various detrimental clinical outcomes. BSPs have recently entered oncological practice as therapy for patients with metastatic bone disease. BSPs bind strongly to bone and in so doing inhibit bone resorption. There is both preclinical and clinical evidence that the BSPs may also have direct antitumour effects. In vitro, BSPs have been shown to induce apoptosis in myeloma cells, and to inhibit matrix metalloproteinase production by prostate cancer cells. Diel et al(see Additional information) reported that in the adjuvant setting, breast cancer patients receiving a BSP had a reduced chance of developing visceral metastases.

\section{Aims}

To determine whether BSPs have direct inhibitory effects on tumour cells in terms of induction of apoptosis, cell invasion and cell migration.

\section{Comments}

This interesting study attempted to elucidate possible further modes of action of the bisphosphonates (BSPs). These agents are rapidly becoming a major component of the treatment of bone metastases in patients with metastatic breast cancer or multiple myeloma. Although proven to have major effects on osteoclast-driven bone resorption, there is increasing evidence that the BSPs possess a more complex variety of biological actions. In particular, work by Diel et al (see Additional information) on the adjuvant treatment of breast cancer suggested that the BSPs may have direct antitumour effects. Although supported by some laboratory data, it is unclear whether this is in fact a real finding. Of two other studies of BSPs in adjuvant breast cancer, one found no impact of BSPs on development of non- 
bony metastases, and the other actually found an increase in non-bony metastases. This study, whilst suggesting that BSPs can affect tumour cell invasion, could not identify the actual mechanism for this effect. Thus, a great deal more work is needed, both in vitro and clinically, in order for the full spectrum of activity of the BSPs to be elucidated. This may have important implications in determining the roles that the BSPs may play in cancer management.

\section{Methods}

Six different BSPs (clodronate, zoledronate, ibandronate, and three analogues of risedronate - one potent [NE-10244], one inactive [NE-58051], and one with a phosphate group substituted by a carboxyl group [NE-10790] were tested on two cells lines. The two cell lines were a human breast (MDAMB-231) and a prostate (PmPC3) cancer line, both highly metastatic to bone. Treated and untreated cells were tested using a cell migration assay, a Matrigel invasion assay, a cell cycle/FACS analysis, an apoptosis assay and an analysis of matrix metalloproteinase (MMP) activity.

\section{Results}

Cell migration assay: none of the BSPs tested inhibited tumour cell migration. Matrigel invasion assay: the BSPs inhibited both breast and prostate cancer cell invasion, reaching $60-90 \%$ inhibition. The most potent inhibitor was zoledronate, and the least potent was clodronate. NE-58051 (inactive) had no effect. NE-10790 (carboxyl substitute) did inhibit migration. Zoledronate, the most potent of the BSPs, did not induce apoptosis in tumour cells. The BSPs did inhibit the proteolytic activity of the three MMPs tested (MMP-2, -9, -12). All the BSPs tested were equipotent in this regard. Interestingly the inactive analogue, NE-58051, also inhibited MMP activity but the carboxyl substitute, NE-10790, did not.

\section{Discussion}

BSP pretreatment of breast and prostate carcinoma cells inhibited cell invasion in a dose-dependent manner. The fact that the inactive analogue NE-58051 had no inhibitory effect, whereas NE-10790 (the carboxyl substitute) did have, indicates that the inhibitory activity of BSPs involves the R2 chain of the molecule. BSPs did not inhibit tumor cell migration at concentrations that inhibited tumor cell invasion, and they did not induce apoptosis in tumor cells. They did, however, inhibit the proteolytic activity of the MMPs. This effect was completely reversed in the presence of an excess of zinc. In addition, NE-10790 did not inhibit MMP activity, suggesting that phosphonate groups of BSPs are responsible for the chelation of zinc and the subsequent inhibition of MMP activity. In conclusion, this study indicates that the BSPs do have a direct effect in preventing cell invasion, with an inhibitory effect on the 
proteolytic activity of MMPs. These results suggest that BSPs may have a role in the prophylactic treatment of patients with cancers that are known to preferentially metastasise to bone.

\section{Additional information}

Boissier S, Magnetto S, Frappart L, Cuzin B, Ebetino FH, Delmas PD, Clezardin P: Bisphosphonates inhibit prostate and breast carcinoma cell adhesion to unmineralized and mineralized bone extracellular matrices. Cancer Res 1997 57:3890-3894 (PubMed\%20abstract)

Diel IJ, Solomayer EF, Costa SD, Gollan C, Goerner R, Wallwiener D, Kaufmann M, Bastert G: Reduction in new metastases in breast cancer with adjuvant clodronate treatment. $N$ Engl $\mathrm{J} \mathrm{Med}$ 1998, 339:357-363 (PubMed\%20abstract)

\section{References}

1. Boissier S, Ferreras M, Peyruchaud O, Magnetto S, Ebetino FH, Colombel M, Delmas P, Delaisse JM, Clezardin P: Bisphosphonates inhibit breast and prostate carcinoma cell invasion, an early event in the formation of bone metastases. Cancer Res. 2000, 60: 2949-2954.

This PDF file was created after publication. 